\title{
Characterization of binding sites and Optimization of cell free bacteria condition for metal bio-sorbents \\ ${ }^{* 1}$ Mostafa G. Fadl, ${ }^{2}$ Zenat Kamel Mohamed *1mostafa_gomaa338@yahoo.com
}

2 zkamel@yahoo.com

\author{
${ }^{1}$ Nuclear Materials Authority, P.O. BOX 530 EL MAADI, Cairo, \\ Egypt \\ ${ }^{2}$ Faculty of science, Microbiology \& Botany Department, Cairo \\ University, Giza Square, Cairo Egypt \\ *Corresponding Author: Mostafa Gomaa Fadl PhD ${ }^{1}$ Nuclear \\ Materials Authority, P.O. BOX 530 EL MAADI, Cairo, Egypt
}

\begin{abstract}
Bacteria a Microscopic organisms are the most inexhaustible and flexible of microorganisms and constitute a huge division of the whole living earthly biomass, certain microorganisms were found to amass metallic components at a high limit Was Known as Bacterial Bio-sorption Due to their little size, capacity to become under controlled conditions, and their Accommodation to an extensive variety of ecological situations; Potent metal bio-sorbents among microorganisms, at low $\mathrm{pH}$ esteems, cell divider ligands are protonated and contend essentially with metals for official. With expanding $\mathrm{pH}$, more ligands, such as amino and carboxyl groups, could be exposed, leading to attraction between these negative charges and the metals, and consequently increment bio-sorption onto the cell surface. Starting with Isolation and identification of heavy metal-resistant bacteria from rock Ore. Studying Factors Affecting Uranium Bio-sorption, Optimization of bacterial growth conditions and optimum for metal uptake by free and immobilized bacterial cells and Desorption ratio of uranium ions adsorbed by Coli. /alginate, All this evidence suggest that functions groups Represented in our study are responsible for metal uptake in our bacterial biomass beside change in peaks position which assigned for it's groups confirm bio-sorption of metal ions from waste due to ions charge interaction comparing with immobilized we found increase in no of binding sites indicate that immobilized bacterial have high efficiency for metal up take which also change in peaks position which assigned for its groups confirm bio-sorption of metal ions from waste due to ions charge interaction, Where the high bio-sorption yield obtained by
\end{abstract}


bacteria, the Uranium \& heavy metal bioremediation process expects microorganisms to be joined to a strong surface.

Key words:

Binding sites, Optimization, cell free bacteria condition for metal bio-sorbents.

\section{Introduction:}

\subsection{Bacterial biomass Biosorbents}

Mann 1990 Reported that Bacteria a Microscopic organisms are the most inexhaustible and flexible of microorganisms and constitute a huge division of the whole living earthly biomass, whose mass is estimated as $\sim 1018 \mathrm{~g}$. In the mid 1980s, certain microorganisms were found to amass metallic components at a high limit Was Known as Bacterial Bio-sorption (Vijayaraghavan and Yun 2008a, b). Due to their little size, capacity to become under controlled conditions, and their Accommodation to an extensive variety of ecological situations; furthermore, inexpensive nutrient sources are readily available for microbes. Potent metal biosorbents among microorganisms incorporate genera Bacillus, Pseudomonas, Streptomyces, Micrococcus, and Escherichia coli. Biosorbents got from bacterial biomass have since turned out to be common The Limits of bio-sorption not just relies upon the sort of metal particles, yet in addition on the bacterial variety, because of varieties in cellular Components Metal particles in solution are adsorbed on bacterial surfaces through interactions with chemical functional gatherings, for example, carboxylate, amine, amide, imidazole, phosphate, thioether, hydroxyl, and other utilitarian gatherings found in cell divider biopolymers The fast energy saw with bacterial biomass speaks to a favorable viewpoint for the plan of wastewater treatment frameworks. Bio-sorption incorporates a blend of a few components, for example, Charge fascination, composition, particle trade, covalent authoritative, van der Waal's forces, adsorption, and micro-precipitation. Very short contact times are for the most part adequate to accomplish a metal-bacterial biomass enduring state. This is because biomass is used in the form of either fine Pellets or wet viable cells, where mass transfer resistances are usually negligible.

\subsection{Bacterial Cell Constituent}


The diameter of typical bacterial cells range from 0.5 to $1.0 \mathrm{~mm}$; however, some are more extensive than $50 \mathrm{~mm}$.), despite the fact that there is an incredible assortment of shapes because of contrasts in hereditary qualities and environment Microorganisms have basic morphology; the most widely recognized microscopic organisms are available in three essential shapes: circular or ovoid (coccus), bar (bacillus, with a round and hollow shape), and winding (spirillum. The little size of microscopic organisms guarantees quick metabolic procedures. A bacterial cell (e.g., E. coli) contains a cell divider, cell film, and the cytoplasmic network which comprises of a few constituents that are not layer enclosed (inclusion bodies, ribosomes, and the nucleoid with it's genetic material). Bacteria are classified as either Gram-positive or Gram-negative Are Classified by the Gram staining Microbes into two principle group cell wall qualities (Beveridge 2001). This grouping partitions (Beveridge 1989; Sleytr and Beveridge 1999). Both cell divider sorts contain a peptidoglycan layer that is rich in carboxylate gatherings and totally encompasses the phone (Beveridge 1989; Langley and Beveridge 1999). Cell divider a general negative charge, because of the nearness of phosphodiester bonds between teichoic acid monomers. The exceptionally charged nature of lipopolysaccharides presents a general negative charge on the Gram-negative cell divider. The anionic useful Gram- gatherings show in the peptidoglycan, teichoic acids, and teichuronic acids of positive microscopic organisms, and the peptidoglycan, phospholipids, and lipopolysaccharides of Gram-negative microbes are the segments fundamentally in charge of the anionic character and metal-restricting capacity of the cell divider (Moat et al. 2002; The peptidoglycan layer in the Gram-positive cell divider is ca. $25 \mathrm{~nm}$ thick, while the Gram-negative peptidoglycan layer is much thinner (ca. $7.5 \mathrm{~nm}$ ). The walls of Gram-positive bacteria consist of three primary components: cytoplasm mixed with peptidoglycan, to which teichoic acids are covalently bound. The envelope of Gram-negative bacteria is more complex than that of Gram-positive bacteria. It consists of two membrane bilayers (the outer and plasma membrane) that are chemically and functionally distinct from one another and sandwich a thin peptidoglycan layer between them. Teichoic acids enable the Gram-positive. Prescott et al. 2002). Extracellular polysaccharides (EPSs) are also Provide ability of binding metals; however, their availability rely on the bacterial species and growth conditions, what's more, they can without much of a stretch be expelled by basic 
mechanical disturbance or concoction washing (Yee and Fein 2001). The cell dividers of bacteria contain a large number of surface functional groups, in which carboxyl is generally the most acidic group in the bacteria. At low $\mathrm{pH}$ esteems, cell divider ligands are protonated and contend essentially with metals for official. With expanding $\mathrm{pH}$, more ligands, such as amino and carboxyl groups, could be exposed, leading to attraction between these negative charges and the metals, and consequently increment bio-sorption onto the cell surface. A few microscopic organisms have extraordinary structures, for example, flagella and the S-layer. Sumin Park and Minhee Lee 2017 Explained that The inner and outer void spaces of the Ca alginate spheriouls were filled During the bio-sorption process with heavy metals such as $\mathrm{Cu}$, $\mathrm{Fe}$, and $\mathrm{S}$, suggesting that heavy metal removal by $\mathrm{Ca}$ alginate beads occurs by not only ion exchange but also by Framing edifices and precipitation

\subsection{The S-layer action in bio-sorption}

The S-layer action is a surface and Para crystalline envelope present in several gatherings of microbes and archaea. This layer is formed from protein or glycoprotein monomers that can self-collect in two-dimensional structures (Sleytr et al. 2003). Slayers are related with lipopolysaccharides Urrutia 1997; Madigan et al. 2000). Porosity is between 30 and $70 \%$ and the diameter of the pore between 2 and $8 \mathrm{~nm}$. This characteristic can be used for metal binding. An imperative normal for this protein is its ability to reassemble once disconnected from the cell (Pollmann et al. 2006). Due to this effect, it can be used for bioremediation. S-layer proteins may execute a catching part of metallic particles in both living and dead cells, being a potential option for bioremediation of substantial metals in the field. Some bacterial cells can produce a capsule outside the bacterial cell wall. They are much hydrated and approximately organized polymers Cases are made out of starches and proteins. of polysaccharides and a couple of comprise of proteins or polymers of amino acids called polypeptides, Container course of action is imperative to metal official (Madigan et al. 2000; Channel et al. 2002). EPSs have a high sub-atomic weight with a wealth of adversely charged practical gatherings (ligands), e.g., carboxyl, hydroxyl, and uronic acids (Sobeck and Higgins 2002; Yan et al. 2008). ).Where the arrangement of bacterial EPS is perplexing, contingent upon the strain and its way of life conditions. EPS amalgamation is likewise announced for a few pseudomonads, 
Zoogloea ramigera, Rhizobium sp., Klebsiella sp., and Bacillus sp. Ordinary constituents of EPS are for the most part polysaccharides and proteins, frequently joined by nucleic acids, lipids, or humic substances (Flemming and Wingender 2001; van Hullebusch et al. 2003).

\subsection{Uranium sequestering mechanism (Bio-sorption)}

Research is in progress to establish bio-sorption as a financially reasonable strategy to trap and accumulate metals. Bio-sorption can serve as a tool for the recovery of precious metals (e.g., from processing solutions or seawater) and for the elimination of poisonous metals (particularly from industrial wastewaters). (SchiewerandVolesky2000). Adsorption and micro-precipitation involve binding of electrically neutral metals without the arrival of a stoichiometric amount of previously bound ions. In precipitation Reactions, the main impetus is interaction between the solute and the solvent, whereas in adsorption affinity amongst sorbent and sorbate is the driving force. On account of physicochemical The mechanism by Which interaction based on physical adsorption, ion exchange, and complexion between metal and functional groups of the cell surface, metal Binding does not depend on cellular metabolism. Tunali et al. (2006) indicate that the bio-sorption of lead and copper by Bacillus sp. involve a particle-exchange mechanism. Since the main mechanism involved in bio-sorption is ion exchange, protons compete with metal captions for the binding sites and for this reason; $\mathrm{pH}$ is the operational condition, which influences the process most strongly.

\section{Factors Affecting Uranium Bio-sorption}

There are many factors affecting the bio-sorption process of Uranium -metal ions by the microorganisms. Some of these components were recognized from the examinations of the bio-sorption procedure, for example, particle fixation, biomass concentration, time, $\mathrm{pH}$ and temperature, while other factors belong to types of biomass such as living or dead, free or immobilized cells, and the biosorptive capacity of cell biomass. Kerkar,S., \& Das, K.,R. (2017) Stated that The contact time where The obstruction between restricting locales because of expanded Biomass dosages cannot be overruled, as this will result in low specific uptake Which played a vital part in the evacuation of $\mathrm{Zn}^{2}$ as (Mishra and Tadepalli 2014) Initial solute 
concentration appears to have an Effect on bio-sorption, with a higher concentration resulting in a high solute uptake (Öztürk 2007; Bueno et al. 2008; Uzel and Ozdemir 2009). Also in Our Study U bio-sorption capacity increase with increasing contact time, Due to as time passed the vacant sites of biosorbent available for adsorption were occupied by the pollutant. while the initial concentration is the significant independent parameter associated with Chrome study Mishra and Tadepalli 2014 in U study increase in initial conc. associated with increase in bio-sorption \% Ion removal Toxic pollutant, Therefore, initially the effluent concentration was very less and then started to increase up to $30 \mathrm{~h}$ and then decreased Gupta, A ., Balomajumder, C.(2016). The important independent parameter for $\mathrm{Pb}^{2}$ and $\mathrm{U}$ removal is the temperature where optimum Temperature for growth of Bacteria ranged from $30-40$ (C). However, $\mathrm{pH}$ value affects strongly in the removal of $\mathrm{Zn}_{2}, \mathrm{~Pb}_{2}$ and $\mathrm{Cr}_{3}$ as (Mishra and Tadepalli 2014) stated in his study also in our study it has significant effect in U removal. Bio-sorption by living cells is temperature dependent, and hence change in this parameter will strongly affect while the bio-sorption processes by nonliving biomass is not significantly affected by the temperature. Gupta, A, Balomajumder, C. (2016).

\section{Immobilization (capsulation) of Bacteria}

In addition to the high bio-sorption yield obtained by bacteria, the heavy metal bioremediation process requires microorganisms to be attached to a solid surface. Surface fixation and cell entrapment are the two methods of immobilization. Distinctive lattices were tried for cell immobilization (Beolchini et al., 2003; Xiangliang et al., 2005). Bolster frameworks appropriate for biomass immobilization incorporate alginate, polyacrylamide, polyvinyl liquor, polysulfone, silica gel, cellulose, and glutaraldehyde (Wang 2002; Vijayaraghavan and Yun 2008a, b). The polymeric grid decides the mechanical quality and synthetic protection of the last bio-sorbent molecule to be used for progressive sorption- desorption cycles, so it is imperative to pick the right immobilization lattice. Akar et al. (2009) measured the bio-sorption of $100 \mathrm{mgL}-1$ of nickel at $\mathrm{pH} 6.5$ to be 33.83 and $7.50 \mathrm{mgg}-1$ for silica gel and Proteus vulgaris, respectively, whereas the immobilized bio-sorbent had a bio-sorption capacity of $45.48 \mathrm{mgg}-1$ under the same conditions. Maximum bio- 
sorption obtained using immobilized biomass provides promise for immobilized cells in a column reactor for the remediation of heavy metals. At $\mathrm{pH} 5.0$, the $\mathrm{Cd}^{2+}$ biosorption capacity of $E$. coli biomass-free PVA beads was $1.30 \mathrm{mgg}-1$, which was significantly lower than the adsorption capacity of PVA-immobilized cells, displaying a capacity of 2.18 and $4.41 \mathrm{mg} / \mathrm{g}$ for biomass loading of 8.42 and $19.5 \mathrm{wt} \%$, respectively (Kao et al. 2009). Although cell entrapment imparts mechanical strength and resistance to chemical and microbial degradation upon the bio-sorbent, the costs of immobilizing agent cannot be ignored. Free cells are not suitable for use in a column, due to their low density and size they tend to plug the bed, resulting in marked declines in pressure. For industrial applications of bio-sorption, it is important to utilize an appropriate immobilization technique to prepare commercial biosorbents which retain the ability of microbial biomass to adsorb metal(s) during the continuous treatment process. The immobilization of biomass in solid structures would create a biosorbent material with the right size, mechanical strength, rigidity, and porosity necessary for use in practical processes. The immobilized materials can be used in a manner similar to ion-exchange resins and activated carbon such as adsorptiondesorption cycles (i.e., recovery of the adsorbed metal, reactivated and reuse of the biomass) (Veglio and Beolchini 1997). In different matrices, tested surface fixation was chosen as the immobilization methodology instead of cell entrapment. Cell immobilization has successfully been achieved mostly in calcium alginate beads, but this matrix also has a high affinity for heavy metals. Metal retention kinetics studies with calcium alginate confirmed that almost $100 \%$ of the metal assayed was retained by the beads (Vullo et al. 2003) and that it is pointless to try to improve heavy metal retention by bacterial cell entrapment in calcium alginate beads (Arica et al. 2001; Davis et al. 2003; Vullo et al. 2003; Arica et al. 2004). Although calcium alginate is useful for entrapping cells in its gel structure, its advantage resides mostly in the reutilization of the entrapped cells. However, the high heavy metal affinity of alginate makes it unusable for the development of continuous industrial processes, as the recovery of the alginic acid would increase the final costs of effluent treatment. 


\section{Materials and methods}

\section{1- Sampling}

U-resistant bacterial strain were separated from the rock ore using nutrient agar (NA) medium and were prepared using peptic Digest of animal tissue $(5 \mathrm{~g} / \mathrm{L})$, beef extract $(3$ $\mathrm{g} / \mathrm{L}), \mathrm{NaCl}(5 \mathrm{~g} / \mathrm{L}$.$) and agar 15 \mathrm{~g} / \mathrm{L}$.

\section{2- Isolation and identification of heavy metal-resistant bacteria from rock Ore.}

The isolated metal-resistant bacteria were amended with different conc. Of $U$ metal. Pour plate was performed in NA medium and was brooded at $37^{\circ} \mathrm{C}$ for $24 \mathrm{~h}$.

\section{3-Determination of heavy metal-resistant bacterial isolates by plate diffusion method}

Heavy metal resistant bacteria were determined by plate diffusion method (Hassen, et al. 1998). U solutions were prepared in different concentrations, say 10, 20, 50, 100,250, 500 and 1000 ppm. Each plate was spread with overnight societies of proper living beings. To each of the plate $100 \mu \mathrm{l}$ of appropriate $\mathrm{U}$ metal salt solutions were added in each wells of $10 \mathrm{~mm}$ in diameter and $4 \mathrm{~mm}$ in depth. NA plates were incubated at $37^{\circ} \mathrm{C}$ for $24 \mathrm{~h}$. After incubation, the zone of inhibition was measured. A zone size less than $1 \mathrm{~mm}$ scored as resistance strain.

\section{Optimization of bacterial growth conditions}

Studying factor affecting bacterial growth Like $\mathrm{pH}$. , Temperature, The cultures were incubated at $37{ }^{\circ} \mathrm{C}$ for $24,48 \mathrm{~h}$ and By Detecting O.D. The development was checked using a spectrophotometer (at $600 \mathrm{~nm}$ ) $120 \mathrm{Min}$.

\section{5- Optimization for heavy metal uptake}

(Gourdon, et al. 1990), (Gong, et al. 2005) (Kiran, et al. 2005) Reported that Temperature, $\mathrm{pH}$, biomass, heavy metal concentrations are factors which influences 
the bio-sorption procedure. Especially, $\mathrm{pH}$ biomass concentration and $\mathrm{U}$ metal concentration on bio-sorption tests were explored by advancement process. The bacterial isolates were inoculated into a series of test tubes containing $5 \mathrm{ml}$ of nutrient broth. The $\mathrm{pH}$ was varied from five to nine $(5,6,7,8$ and 9$)$ by adjusting the medium amended with $\mathrm{U}$. The biomass concentration was varied from 1 to $5 \%(1,2,3,4$ and 5 ) in the medium containing $25 \mathrm{mg} / \mathrm{L}$ of $\mathrm{U}$. The heavy metal concentration was varied from $20 \mathrm{mg} / \mathrm{L}$ to $100 \mathrm{mg} / \mathrm{L}(20,40,60,80$ and $100 \mathrm{mg} / \mathrm{L})$.

\section{6- Heavy metal adsorption by the immobilized bacterial cells} the immobilized bacterial cells were set up as dabs agreeing o the strategy of Leung, et al. (2000) and were maintained in the conical flask containing $50 \mathrm{ml}$ of samples for incubation, after which the specimens were pulled back for substantial metal examination by utilizing Titration method .

\section{Cultivation of E. coli.}

Cultivation of E. coli. Was done in $250 \mathrm{~mL}$ cone shaped flasks with $100 \mathrm{~mL}$ culture medium on a rotary shaker at $200 \mathrm{rpm}$ at a constant temperature of $37^{\circ} \mathrm{C}$. The way of culture medium contained The $\mathrm{pH}$ of the medium was adjusted to (6).

\section{Determination of Uranium:}

The uranium content of the sample and prepared standard and treated solution were determined according to the method Described by (Davies \&gray, 1964).

\section{Application of the FTIR spectra of U loaded and unloaded free and immobilized cells.}

10. Preparation of immobilized bacterial biomass beads/alginate-chitosan

microcapsule was composed of $E$. coli sodium alginate, chitosan and calcium

chloride. Therefore, under sterile conditions, the bacteria were mixed with sodium

alginate solution, and then the mixed solution was dropped into calcium chloride

solution for immobilization using a microcapsule preparation instrument. The E. coli Capsule-loaded calcium alginate gel beads were obtained after immobilization, and the loaded calcium alginate gel beads were mixed with chitosan solution to obtain $E$. coli Capsule/alginate-chitosan microcapsules. The microcapsule system had good mechanical strength, flexibility and biocompatibility between the E. coli Capsule and 
the microcapsule. In addition, the internal three-dimensional network structure of the microcapsule provided a sufficient space for the E. coli Capsule growth and good encapsulating stability.

\section{Results \& Discussion}

\section{Characterization Uranium-resistant bacterial isolates}

\subsection{Screening of Uranium-resistant bacterial isolates growth in} presence of Different Uranium conc. Isolated from Aborshid Uranyle rock sample. From 10 bacterial isolate 6 stable isolate where studied to elect the most potent bacterial isolate to be utilized as bacterial capsule in our study.

\begin{tabular}{|c|c|c|c|c|c|}
\hline $\begin{array}{c}\text { Uranium conc. } \\
\text { Isolate no. }\end{array}$ & $100 \mathrm{ppm}$ & $200 \mathrm{ppm}$ & $300 \mathrm{ppm}$ & $600 \mathrm{ppm}$ & $1000 \mathrm{ppm}$ \\
\hline S6 & ++ & + & + & + & + \\
\hline S4 & + & + & + & + & + \\
\hline S5 & + & + & + & + & + \\
\hline S7 & + & + & + & +- & +- \\
\hline S8 & +- & - & - & - & - \\
\hline
\end{tabular}


Table -1.a Test for Screening of uranium resistant isolates

Table 1 represents that we was have 6-10 Isolates tested for incubation with different conc. Of Uranium and investigate strong of growth against $\mathrm{U}$ conc. We found that the most potent isolate S6, S5. Which it's Growth continue with stability up to $1000 \mathrm{ppm}$ Uranium conc. This will continue with us

Table. 1. b. Growth of bacteria in different concentrations of Waste.

\begin{tabular}{|c|c|c|c|}
\hline WASTE CONC. & $10 \%$ & $20 \%$ & CONC. soln. \\
\hline S6 & ++ & + & + \\
\hline S5 & + & + & + \\
\hline S7 & -+ & -+ & - \\
\hline S8 & -+ & -+ & - \\
\hline S3 & + & + & + \\
\hline
\end{tabular}

Previous Table indicates that also the most potent isolates were S6, S5.

\begin{tabular}{|c|c|c|c|}
\hline U conc. & S6 & S4 & S3 \\
\hline 10 & 2 & 2 & 2 \\
\hline 20 & 2 & 2 & 2 \\
\hline 40 & 2 & 2 & 2 \\
\hline 60 & 2 & 4 & 2 \\
\hline 80 & 2 & 4 & 2 \\
\hline 100 & 2 & 4 & 2 \\
\hline 200 & 2 & 5 & 5 \\
\hline 300 & 2 & 5 & $\mathbf{5}$ \\
\hline 600 & 2 & $\mathbf{6}$ & $\mathbf{8}$ \\
\hline 1000 & 2 & $\mathbf{6}$ & $\mathbf{8}$ \\
\hline
\end{tabular}

Table .1.C. Growth of bacteria in different concentrations of Uranium by plate diffusion method

This Table confirm that what we found in Previous Tables a,b that inhibition zone indicate metal resistant bacterial isolates . 


\subsection{Optimum condition for Growth bacterial isolates:}

Optimizing a growth medium is very important to study the performance of microbes in bio-sorption Processes.

\begin{tabular}{|c|c|}
\hline $\mathbf{p H}$ & O.D.(24hr) \\
\hline $\mathbf{4}$ & 0.313 \\
\hline $\mathbf{5}$ & 0.409 \\
\hline $\mathbf{6}$ & 0.469 \\
\hline $\mathbf{7}$ & 0.354 \\
\hline $\mathbf{8}$ & 0.213 \\
\hline
\end{tabular}

Table: 2-a Cellular Growth of Bacteria (Growth Curve of bacteria at different $\mathrm{PH}$.

Hypothesis, that 6.0 is the optimal pH for E. coli growth was accepted. The radii of the restraint zones around the test plates were little contrasted with those of the anti-toxin test. This could be due to the concentration of the varying $\mathrm{pH}$ substances being too low to show the full affect of the $\mathrm{pH}$. The results were not considered anomalous, however, because they do show a direct correlation between the $\mathrm{pH}$ and inhibition of the E. coli. To further improve this experiment, higher concentrations of each of the varying $\mathrm{pH}$ solutions would be used so that the effect that the $\mathrm{pH}$ has on the E. coli is much clearer. In addition, more varying pH solutions would be tested. The difference between a pH of 2.4 and 7.0 is quite large, as is the difference between $\mathrm{pH} 7.0$ and 11.6. The maximum tolerable $\mathrm{pH}$ of $E$. coli may not have been 7.0 , but $\mathrm{pH} 11.6$ was the next tested $\mathrm{pH}$ after 7.0, and 11.6 was too basic for the E. coli to survive. So, all that can be concluded about the maximum $\mathrm{pH}$ is that it is between 6.0 and 11.6. Further $\mathrm{pH}$ values would need to be tested in order to obtain a more accurate estimate of the maximum $\mathrm{pH}$ for E. coli growth. Similarly, the minimum $\mathrm{pH}$ for $E$. coli growth may be somewhere between 
$\mathrm{pH} 0.0$ and 2.4, however further $\mathrm{pH}$ values would need to be tested to find the actual minimum $\mathrm{pH}$ for $E$. coli growth. Further-more, $\mathrm{pH} 2.4$ may have been an anomalous result. However, because there were no other tested $\mathrm{pH}$ values between 2.4 and 7.0 , it is not certain that the $\mathrm{pH}$ of 2.4 is the true minimum $\mathrm{pH}$ that $E$. coli can tolerate.

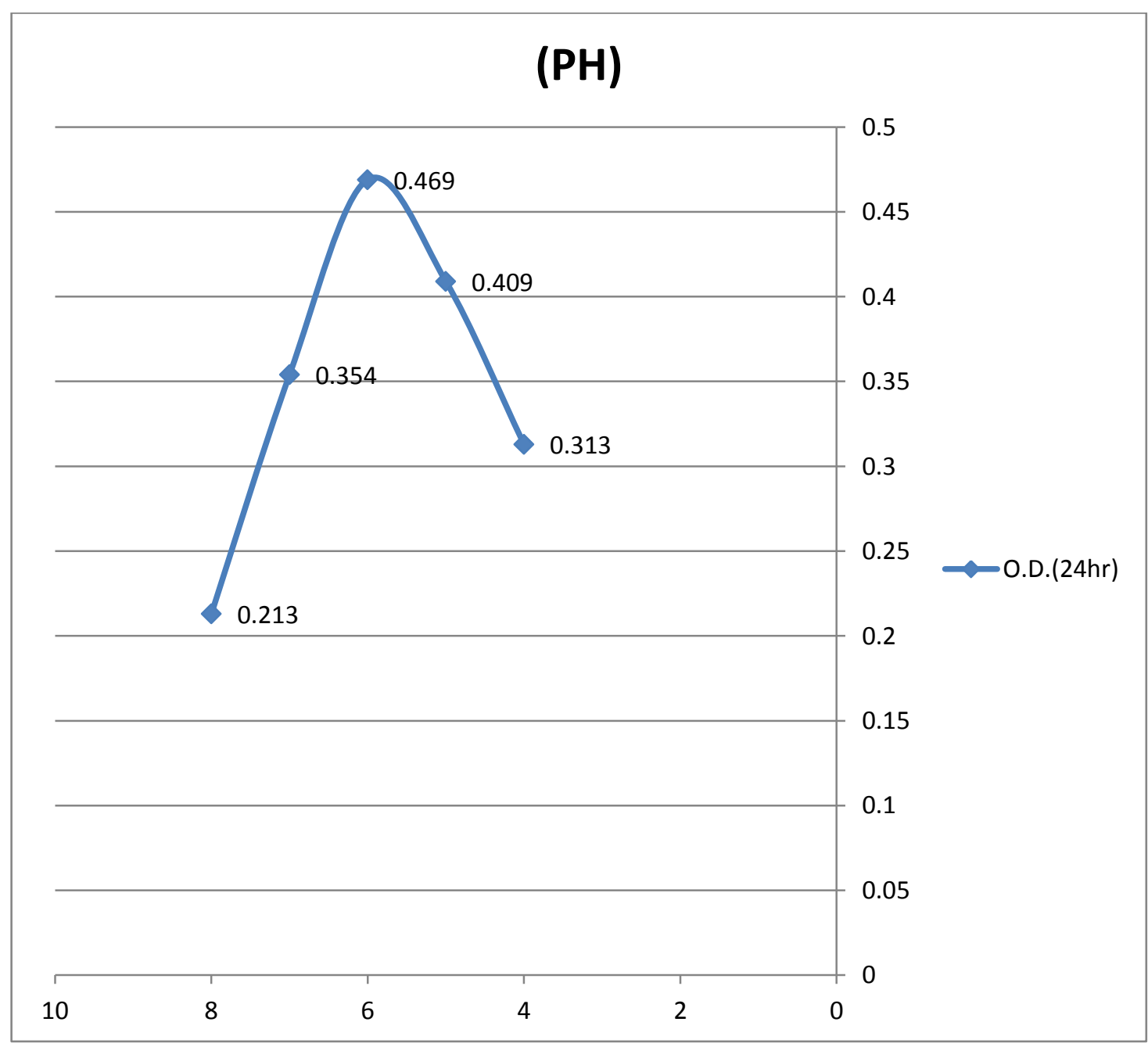

Table: 2-bCellular Growth of Bacteria (Growth Curve of bacteria at Different pH)

\begin{tabular}{|c|c|c|c|c|}
\hline Time & PH. 4 & PH. 5 & PH. 6 & PH. 7 \\
\hline 0 time & 0.0411 & 0.0511 & 0.0551 & 0.0501 \\
\hline $20 \mathrm{~min}$ & 0.029012 & 0.03412 & 0.03912 & 0.04012 \\
\hline $40 \mathrm{~min}$ & 0.0342 & 0.0542 & 0.0642 & 0.0542 \\
\hline $60 \mathrm{~min}$ & 0.0442 & 0.0642 & 0.0542 & 0.0642 \\
\hline $80 \mathrm{~min}$ & 0.0605 & 0.0505 & 0.0705 & 0.0705 \\
\hline $100 \mathrm{~min}$ & 0.0459 & 0.0459 & 0.0459 & 0.0459 \\
\hline
\end{tabular}




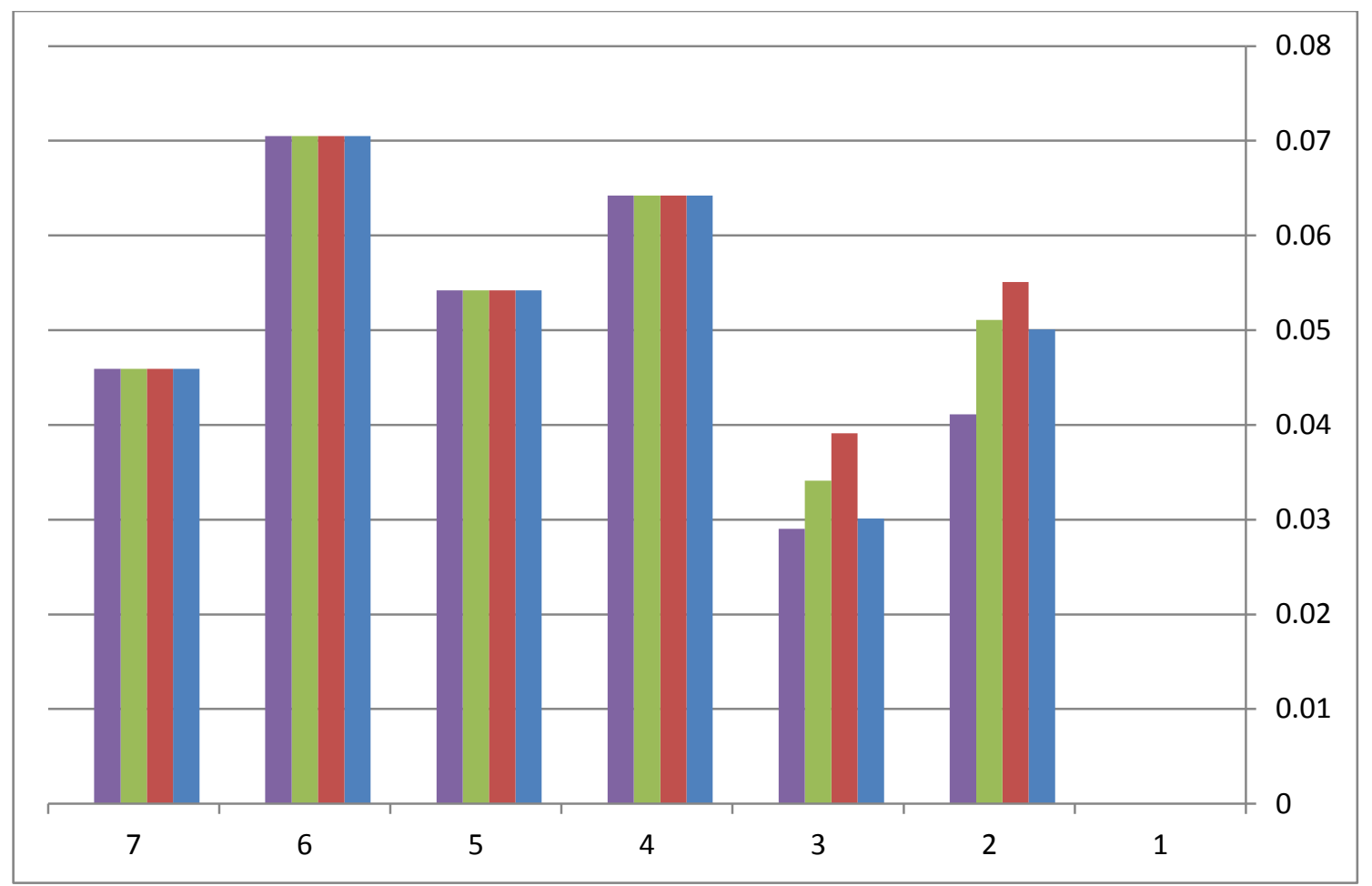

Table: 2-c Cellular Growth of Bacteria (Growth Curve of bacteria at Different Temperatures)

\begin{tabular}{|c|c|c|c|}
\hline Time & $\mathbf{1 0 - 2 0}$ & $\mathbf{3 0 - 5 0}$ & $\mathbf{5 0 - 6 0}$ \\
\hline $0 \mathrm{~min}$. & 0.0411 & 0.0511 & 0.0551 \\
\hline $20 \mathrm{~min}$ & 0.029012 & 0.03412 & 0.03912 \\
\hline $40 \mathrm{~min}$ & 0.0442 & 0.0642 & 0.0542 \\
\hline $60 \mathrm{~min}$ & 0.0542 & 0.0562 & 0.0532 \\
\hline $80 \mathrm{~min}$ & 0.0705 & 0.0755 & 0.065 \\
\hline $100 \mathrm{~min}$ & 0.0449 & 0.0459 & 0.0439 \\
\hline
\end{tabular}

Temperature, like $\mathrm{pH}$, affects the activity of enzymes. The results show a direct correlation between the temperature and $E$. coli growth as shown in Table 4 and Figure 7 . The hypothesis, that the optimal temperature for $E$. coli growth is 370 C), was conformed. The most and largest colonies were present on the temperature test plate that was placed in the incubator set at $37^{\circ}$ C.As with the case of varying $\mathrm{pH}$, when the temperature is changed to a temperature outside the tolerable range of an enzyme; the enzyme becomes denatured and cannot function. This is what was happening in the $E$. coli bacteria that were on test plates in the refrigerator and. The E. coli on the test plates in $45^{\circ} \mathrm{C}$ and $50^{\circ} \mathrm{C}$ were able to survive, but as the temperature increased from $37^{\circ}$ 
$\mathrm{C}$ to50 ${ }^{\circ} \mathrm{C}$, the size and number of colonies decreased. The hypothesis, that the optimal temperature for $E$. coli growth is $37^{\circ} \mathrm{C}$ was accepted.

Table: 2-d Cellular Growth of Bacteria (Growth Curve of bacteria at Different Initial Biomass)

\begin{tabular}{|c|c|c|}
\hline Biomass conc. & O.D. at 500 & $24 \mathrm{hr}$. \\
\hline $0.1 \mathrm{ml}$ & 0.02661 & 0.152 \\
\hline $0.5 \mathrm{ml}$ & 0.0549 & 0.688 \\
\hline $1 \mathrm{ml}$ & 0.07311 & 0.698 \\
\hline
\end{tabular}

In our study bacteria capsule as we mentioned have standard dosage as 3\% of the volume but we study the bacteria inoculum to get optimum turbidity, which reflect optimum growth to obtain high viability with available active sites.

Table: 2-ECellular Growth of Bacteria (Growth Curve of bacteria at Different Initial Biomass)

\begin{tabular}{|c|c|c|c|}
\hline Time & $\begin{array}{c}\text { Biomass conc. } \\
0.1 \mathrm{ml} \text { (O.D.600nm }\end{array}$ & $\begin{array}{c}\text { Biomass conc. } \\
\text { o.5ml(O.D.600nm }\end{array}$ & $\begin{array}{c}\text { Biomass } \\
\text { conc. 1ml } \\
\text { O.D.600nm }\end{array}$ \\
\hline 0 time & 0.02661 & 0.0149 & 0.07311 \\
\hline $20 \mathrm{~min}$ & 0.029012 & 0.03412 & 0.03912 \\
\hline $40 \mathrm{~min}$ & 0.0342 & 0.0442 & 0.0540 \\
\hline $60 \mathrm{~min}$ & 0.0542 & 0.0502 & 0.0641 \\
\hline $80 \mathrm{~min}$ & 0.0605 & 0.0725 & 0.0705 \\
\hline $100 \mathrm{~min}$ & 0.0409 & 0.0439 & 0.0459 \\
\hline
\end{tabular}

Regarding to Table 2 the dosage of a bacterial biomass strongly influences degree of bio-sorption. An expansion in biomass fixation by and large builds the measure of solute biosorbed, because of the expanded surface zone of the cell wall, which thusly expands the quantity of restricting destinations while the amount of metal solute per unit weight of biomass diminishes with an expanding biosorbent dose, which might 
be because of the perplexing connection of a few elements. An essential factor at high sorbent doses is that the accessible solute is deficient to totally cover the accessible replaceable destinations on the biosorbent, as a rule bringing about low solute take-up. The obstruction between restricting locales because of expanded biosorbent doses can't be overruled, as this will bring about low particular take-up.

\section{Optimum Condition for bio sorption Process}

Initial solute concentration appears to have an impact on bio-sorption, with a higher concentration resulting in a high solute uptake

Table: 3 Cellular Growth of bacteria in different concentrations of Uranium by O.D. $600 \mathrm{~nm}$ method.

\begin{tabular}{|c|c|c|}
\hline U CONC. & Qe (sorption \%) & O.D. \\
\hline $20 \mathrm{ppm}$ & $100 \%$ & 0.05 \\
\hline $50 \mathrm{ppm}$ & $100 \%$ & 0.0490 \\
\hline $100 \mathrm{ppm}$ & $100 \%$ & 0.0459 \\
\hline $250 \mathrm{ppm}$ & $100 \%$ & 0.0438 \\
\hline $500 \mathrm{ppm}$ & $100 \%$ & 0.0468 \\
\hline $1000 \mathrm{ppm}$ & $93 \%$ & 0.0389 \\
\hline
\end{tabular}

Bueno et al. 2008; Uzel and Ozdemir 2009 reported that . This occurs because at lower initial solute concentrations, the ratio of the initial moles of solute to the available surface area is low; subsequently, the fractional sorption becomes independent of the initial concentration. However, at higher concentrations, the sites available for sorption become fewer compared with the moles of solute present and, hence, the removal of solute is strongly dependent upon initial solute concentration.

\subsection{Effect of $\mathbf{p H}$ bio sorption Process}

As a rule, expanding $\mathrm{pH}$ builds the negative charge on the cell surface until the point that all applicable practical gatherings are deprotonated, which favors electrochemical fascination and adsorption of inscriptions Moreover, the expansion in metal take-up with an expansion in $\mathrm{pH}$ might be the aftereffect of more proficient rivalry of captions with $\mathrm{H}^{+}$for restricting locales on microscopic organisms Where it influences the arrangement science of metal particles and the surface practical gatherings of the bacterial cell divider It additionally influences the solvency of the metal particles in 
the arrangement, where $\mathrm{H}^{+}$particles supplant a portion of the positive particles from the biomass s (Long et al. 2014. Detaile0\[od that the $\mathrm{pH}$ is an essential parameter, which. The bio-sorption limit of metal subtitles increments with increment in $\mathrm{pH}$ esteems, and this might be because of the more negative restricting destinations uncovered on Bacterial surface (Aksu and Gulen 2002). Announced that at low pH esteems are blocked and connected with hydrogen particles that prevent the entrance of metal cations because of ghastly powers to the surface useful gatherings. While (Aryal et al. 2010; Ziagova et al. 2007) Stated that, biosorption proficiency of metal anions increments with diminish in $\mathrm{pH}$ esteems because of the expansion in emphatically charged Bacterial surface gatherings, while at higher $\mathrm{pH}$, the shocking powers between metal anions and adversely charged biomass surface reduce the metal take-up limit (Aryal and Liakopoulou Kyriakides 2013b Reported that bio-sorption of metal increased with increasing $\mathrm{pH}$ from 1.0 to 5.0 and decreased upon further increase to 7.0, The decrease in the sorption efficiency at $\mathrm{pH}$ higher than 5.0 may be due to the precipitation of as hydroxide, now in our study as previous mentioned above Table 3 that $\mathrm{pH}$. 5and 6 are the most favorable for bio-sorption in that waste where higher $\mathrm{pH}$ availability of precipitation occur prevent accurate detection of uranium bio-sorpion But in our case of waste of high content 100, 250 ,500and 1000 ppm First result waste of $100 \mathrm{ppm}$ content after $24 \mathrm{hr}$ incubation time $\mathrm{U}$ reside is Nil at that $\mathrm{pH}(6)$

Table: 3 a. Cellular Growth of bacterial isolates (O.D. at 500) in response to various biomass concentrations and $100 \mathrm{ppm}$. Temperature 37 $\square$ C, incubation time: $24 \mathrm{~h}$.

\begin{tabular}{|c|c|c|c|}
\hline Biomass conc. & 0 time & $\mathbf{2 4} \mathbf{~ h r}$ & Qe \% \\
\hline $.1 \mathrm{ml}$ & 0.02661 & 0.598 & $100 \%$ \\
\hline $0.5 \mathrm{ml}$ & 0.0149 & 0.152 & $100 \%$ \\
\hline $1 \mathrm{ml}$ & 0.07311 & 0.698 & $100 \%$ \\
\hline
\end{tabular}

\subsection{Effect of biomass concentration on bio-sorption process.}

Bio-sorption of Uranium substantial metals wards on biomass fixation utilized as the sorption medium. An expansion in biomass fixation as a rule brings about increment 
of bio-sorption productivity, likely because of the increment in the quantity of restricting destinations. It was watched that the sorption productivity expanded with increment in biomass fixation, however biomass focuses over 1.0 and $2.0 \mathrm{~g} / \mathrm{L}$ had bring down effect in sorption proficiency of As (III) and As (V), individually (Aryal et al. 2010) This lower augment in rate expulsion above ideal biomass fixation might be credited to the obstruction between Capacity Gathering. A few investigations have brought up that take-up limit of Uranium\& overwhelming metals diminishes with expanding the biomass focus because of solid impediments of ionic species portability in the bio-sorption medium, abandoning some coupling locales for metal particles unsaturated. (Aryal et al. 2012; Tangaromsuk et al. 2002). In Incharoensakdi et al study expressed that The particular take-up of $\mathrm{Zn}$ (II) decreased, when Microbial biomass fixation surpassed as $0.2 \mathrm{~g} / \mathrm{L}$ (Incharoensakdi and Kitjaharn 2002). Ziagova et al. (2007) detailed the huge increment in the Cr (VI) take-up productivity, when the biomass convergence of Staphylococcus xylosus expanded metal anion did not change fundamentally over $1.0 \mathrm{~g} / \mathrm{L}$ of Bacterial biomass from 1.0 to $8.0 \mathrm{~g} / \mathrm{L}$, though expulsion effectiveness if there should be an occurrence of our investigation we utilize immobilized mass by infuse $3 \mathrm{ml}$ of bacterial biomass in $100 \mathrm{ml}$ ca.alginate water.

Table: 3b. Sorption \% of bacteria at Different Temperatures.

\begin{tabular}{|c|c|c|c|}
\hline Temperature Range & O.D. at 500 & 24 hr. & Qe \% \\
\hline $10-20$ & 0.02461 & 0.1520. & $70 \%$ \\
\hline $30-50$ & 0.0149 & 0.678 & $100 \%$ \\
\hline $50-60$ & 0.07311 & 0.398 & $60 \%$ \\
\hline
\end{tabular}

We know that optimum temperature for growth of bacteria in general ranges from 3050 so optical densities increase consequently binding sites increase so bio-sorption capacity of bacterial isolates increase .where it in low temperature low O.D. so low binding sites so sorption capacity decrease where in high temperature moderate O.D. but also still binding sites active and capacity moderate high comparing with low temperature. So optimum temperature for bio-sorption process rages between 30-50. 
Table: 3C. Cellular growth at 100-ppm U standard

\begin{tabular}{|c|c|}
\hline Time & O.D. at 500nm \\
\hline 0 time & 0.0511 \\
\hline $20 \mathrm{~min}$ & 0.03012 \\
\hline $40 \mathrm{~min}$ & 0.0542 \\
\hline $60 \mathrm{~min}$ & 0.0442 \\
\hline $80 \mathrm{~min}$ & 0.0505 \\
\hline $100 \mathrm{~min}$ & 0.0359 \\
\hline
\end{tabular}

Table: 3d. Incubation time w U20ppmO.D.at 500nm

\begin{tabular}{|c|c|}
\hline Incubation time w U 20 ppm & $\underline{\text { O.D.at 500nm }}$ \\
\hline 0 time & 0.0411 \\
\hline $20 \mathrm{~min}$ & 0.0301 \\
\hline $40 \mathrm{~min}$ & 0.0602 \\
\hline $60 \mathrm{~min}$ & 0.0542 \\
\hline $80 \mathrm{~min}$ & 0.0605 \\
\hline $100 \mathrm{~min}$ & 0.0459 \\
\hline
\end{tabular}

The uptake of Uranium is examined at time interval and the result are shown table 3 as can be seen in table that during the first 50 min of the experiment the concentration of Uranium adsorbed by immobilized bacterial isolate increases with increase from 50 to $120 \mathrm{~min}$ no change in concentrations observed in time our experiment $24 \mathrm{hr}$. were selected to confirm adsorption equilibrium .

\begin{tabular}{|c|c|c|c|}
\hline Incubation time & U Conc. 250 & U con.500 & Uconc.1000 \\
\hline $24 \mathrm{hr}$. & $100 \%$ & $100 \%$ & $98 \%$ \\
\hline $72 \mathrm{hr}$. & $100 \%$ & $100 \%$ & $100 \%$ \\
\hline
\end{tabular}

Table: 4 for Effect of contact time on bio-sorption efficiency. 


\subsection{Techniques Used in Metal Bio-sorption Studies}

In study of. Jian-hua et al. (2007) In investigation of. Jian-hua et al. (2007) he effectively associated the amount of acidic gatherings introduce on Bacillus cereus biomass, decided through potentiometric titrations, with the metal take-up limit. The idea of the coupling locales and their inclusion amid bio-sorption can be roughly assessed utilizing FTIR. So we utilize FTIR systems to decide The idea of the coupling locales where investigation of Mishra and Doble (2008) indicated that carboxyl and amino groups were responsible for the binding of chromate, Carboxyl groups are negatively charged and abundantly available, actively participate in binding of metal cations.. Kang et al. (2007) observed that amine groups protonated at $\mathrm{pH} 3$ and attracted negatively charged chromate ions via electrostatic interaction. Potentiometric titrations can provide information on type and number of binding sites. Kang et al. (2007) titrated Pseudomonas aeruginosa and determined the $\mathrm{pKa}$ values of available binding sites Loukidou et al. (2004).

\subsection{Analyzed the FTIR spectra of U loaded and unloaded}

we use FT-IR spectra as to confirmed availability of binding sites as shown in Table : 5a Table : 5b for Uranium we found Amino acid $(\mathrm{O}-\mathrm{H})$ Stretching protein $\mathrm{v}(\mathrm{N}-\mathrm{H})$ stretching, Phosphate C-O Stretching band ,P-H stretching, Protein amide I band mainly $(\mathrm{C}=\mathrm{O})$ Stretching, Protein $\left(\mathrm{CH}_{2}\right)$ and $\left(\mathrm{CH}_{3}\right)$ bending of methyle Lipid $\left(\mathrm{CH}_{2}\right)$ bending of methyl, Carbohydrate (c-o) of polysaccharides, Nucleic acid (other phosphate containing compound $),>\mathrm{p}=\mathrm{o}$ stretching of phosphodiester, acid chlorides C-Cl stretch in S6 E coli, and comparing with dead isolate we found the same Beside acid chlorides at position $550 \mathrm{~cm}^{-1} \mathrm{C}-\mathrm{Cl}$ stretch Cayllahua et al. (2009) study who used FTIR spectra to confirm the presence of amide, carboxyl, and phosphate groups in Rhodococcus sp. Biomass 
Table: 5a data of FT-IR OF un loaded $E$. coli. (S6) unloaded and Bacterial Isolate.

\begin{tabular}{|l|l|l|l|}
\hline Wave number range & Typical band & $\begin{array}{l}\text { Intensity of loaded } \\
\text { band live bacteria }\end{array}$ & Main peak(cm $\left.{ }^{-\mathbf{1}}\right)$ \\
\hline $3029-3639$ & $\begin{array}{l}\text { Amino acid(O-H) stretching protein v(N-H) } \\
\text { stretching }\end{array}$ & 77.9 & $1-3439.42$ \\
\hline $2344-2365$ & Phosphate C-O Stretching band ,P-H stretching & 93 & $2-2355.62$ \\
\hline $1583-1709$ & Protein amide I band mainly(C=O) Streching & 90 & $3-1638.23$ \\
\hline $1425-1477$ & $\begin{array}{l}\text { Protien }\left(\mathrm{CH}_{2}\right) \text { and }\left(\mathrm{CH}_{3}\right) \text { bending of methyle } \\
\text { Lipid }\left(\mathrm{CH}_{2}\right) \text { bending of methyl }\end{array}$ & 95 & $4-1428.99$ \\
\hline $1072-1356$ & $\begin{array}{l}\text { Carbohydrate (c-o) of polysaccharides, } \\
\text { Nucleic acid (other phosphate containing compound } \\
>\text { p=o stretching of phosphodiester }\end{array}$ & 100 & $5-1101.15$ \\
\hline $730-550$ & acid chlorides C-Cl stretch & 97 & $6-556.363$ \\
\hline
\end{tabular}

Table: 5b data of FT-IR OF unloaded E. coli. (S6) loaded Bacterial Isolate.

\begin{tabular}{|c|c|c|c|}
\hline Main peak $\left(\mathrm{cm}^{-1}\right)$ & $\begin{array}{l}\text { Intensity of } \\
\text { loaded band }\end{array}$ & Typical band & $\begin{array}{c}\text { Wave number } \\
\text { range }\end{array}$ \\
\hline $1-3455.42$ & 50.4 & $\begin{array}{l}\text { Amino acid }(\mathrm{O}-\mathrm{H}) \\
\text { stretching protein } \\
\mathrm{v}(\mathrm{N}-\mathrm{H}) \text { stretching }\end{array}$ & 3029-3639 \\
\hline $2-2088.62$ & 99 & $\begin{array}{l}\text { Phosphate C-O } \\
\text { Stretching band ,P- } \\
\text { H stretching }\end{array}$ & $2344-2365$ \\
\hline $3-1641.23$ & 78 & $\begin{array}{c}\text { Protein amide I } \\
\text { band mainly }(\mathrm{C}=\mathrm{O}) \\
\text { Streching }\end{array}$ & $1583-1709$ \\
\hline $4-1428.99$ & 96 & $\begin{array}{l}\text { Protien }\left(\mathrm{CH}_{2}\right) \text { and } \\
\left(\mathrm{CH}_{3}\right) \text { bending of } \\
\text { methyle Lipid } \\
\left(\mathrm{CH}_{2}\right) \text { bending of } \\
\text { methyl }\end{array}$ & $1425-1477$ \\
\hline $5-1109.15$ & 105 & $\begin{array}{l}\text { Carbohydrate (c-o) } \\
\text { of polysaccharides, } \\
\text { Nucleic acid (other } \\
\text { phosphate } \\
\text { containing } \\
\text { compound ) } \\
>\mathrm{p}=0 \text { stretching of } \\
\text { phosphodiester }\end{array}$ & $1072-1356$ \\
\hline $6-593.363$ & 92 & $\begin{array}{r}\text { acid chlorides } \mathrm{C}- \\
\text { Cl stretch }\end{array}$ & $730-550$ \\
\hline $7-550.577$ & 92 & $\begin{array}{r}\text { acid chlorides C- } \\
\mathrm{Cl} \text { stretch }\end{array}$ & $730-550$ \\
\hline
\end{tabular}


A few band changes enabled the creators to anticipate the conceivable contribution of amino, carbonyl, carboxyl, and phosphate bunches in the bio-sorption of Uranium.

Table: 5c data of FT-IR OF unloaded immobilized E. coli. (S6) Bacterial Isolate.

\begin{tabular}{|c|c|c|c|}
\hline Main peak $\left(\mathrm{cm}^{-1}\right)$ & $\begin{array}{c}\text { Intensity of loaded } \\
\text { band }\end{array}$ & Typical band & $\begin{array}{c}\text { Wave number } \\
\text { range }\end{array}$ \\
\hline $1-3436.42$ & 71.14 & $\begin{array}{l}\text { Amino acid }(\mathrm{O}-\mathrm{H}) \\
\text { stretching protein } \\
\mathrm{v}(\mathrm{N}-\mathrm{H}) \text { stretching }\end{array}$ & 3029-3639 \\
\hline $2-1725.23$ & 97 & $\begin{array}{l}\text { Phosphate C-O } \\
\text { Stretching band ,P- } \\
\text { H stretching }\end{array}$ & $2344-2365$ \\
\hline $3-1636.3$ & 92 & $\begin{array}{l}\text { Protein amide I band } \\
\text { mainly }(\mathrm{C}=\mathrm{O}) \\
\text { Streching }\end{array}$ & $1583-1709$ \\
\hline 4-1380.99 & 86 & $\begin{array}{l}\text { Protien }\left(\mathrm{CH}_{2}\right) \text { and } \\
\left(\mathrm{CH}_{3}\right) \text { bending of } \\
\text { methyle Lipid }\left(\mathrm{CH}_{2}\right) \\
\text { bending of methyl }\end{array}$ & $1425-1477$ \\
\hline $5-1354.15$ & 80 & $\begin{array}{l}\text { Carbohydrate (c-o) } \\
\text { of polysaccharides, } \\
\text { Nucleic acid (other } \\
\text { phosphate } \\
\text { containing } \\
\text { compound ) } \\
>\text { p =o stretching of } \\
\text { phosphodiester }\end{array}$ & $1072-1356$ \\
\hline 6-1038.48 & 91.90 & $\begin{array}{l}\text { Carbohydrate (c-o) } \\
\text { of polysaccharides, } \\
\text { Nucleic acid (other } \\
\text { phosphate } \\
\text { containing } \\
\text { compound ) } \\
>\text { p=o stretching of } \\
\text { phosphodiester }\end{array}$ & $1072-1356$ \\
\hline $7-924.7 .363$ & 99 & $\begin{array}{l}\text { acid chlorides C- } \\
\mathrm{Cl} \text { stretch }\end{array}$ & $730-550$ \\
\hline $8-879.577$ & 99 & $\begin{array}{l}\text { acid chlorides } \mathrm{C}- \\
\mathrm{Cl} \text { stretch }\end{array}$ & $730-550$ \\
\hline $9-808.992$ & 98 & $\begin{array}{l}\text { acid chlorides C- } \\
\mathrm{Cl} \text { stretch }\end{array}$ & $730-550$ \\
\hline $10-597$ & 88 & $\begin{array}{l}\text { acid chlorides C- } \\
\text { Cl stretch }\end{array}$ & $730-550$ \\
\hline
\end{tabular}

All this evidence suggest that functions groups Represented in table (5a, 5b, 5c, 5d) are responsible for metal uptake in our bacterial biomass beside change in peaks 
position which assigned for it's groups confirm bio-sorption of metal ions from waste due to ions charge interaction comparing table $5 \mathrm{a}, 5 \mathrm{~b}$ with $5 \mathrm{c}, 5 \mathrm{~d}$ we found increase in no of binding sites indicate that immobilized bacterial have high efficiency for metal up take which also change in peaks position which assigned for it's groups confirm bio-sorption of metal ions from waste due to ions charge interaction .

Table: $5 \mathrm{~d}$ data of FT-IR OF loaded immobilized $E$. coli. (S6) Bacterial Isolates.

\begin{tabular}{|c|c|c|c|}
\hline Main peak $\left(\mathrm{cm}^{-1}\right)$ & $\begin{array}{c}\text { Intensity of loaded } \\
\text { band }\end{array}$ & Typical band & $\begin{array}{c}\text { Wave number } \\
\text { range }\end{array}$ \\
\hline $1-3909.42$ & 96.64 & $\begin{array}{l}\text { Amino } \operatorname{acid}(\mathrm{O}-\mathrm{H}) \\
\text { stretching protein } \mathrm{v}(\mathrm{N}- \\
\mathrm{H}) \text { stretching }\end{array}$ & 3029-3639 \\
\hline $2-3859.23$ & 96 & $\begin{array}{c}\text { Phosphate C-O } \\
\text { Stretching band ,P-H } \\
\text { stretching }\end{array}$ & $2344-2365$ \\
\hline $3-1636.3$ & 92 & $\begin{array}{l}\text { Protein amide I band } \\
\text { mainly }(\mathrm{C}=\mathrm{O}) \text { Streching }\end{array}$ & $1583-1709$ \\
\hline $4-1729.99$ & 93 & $\begin{array}{c}\text { Protien }\left(\mathrm{CH}_{2}\right) \text { and } \\
\left(\mathrm{CH}_{3}\right) \text { bending of } \\
\text { methyle Lipid }\left(\mathrm{CH}_{2}\right) \\
\text { bending of methyl }\end{array}$ & $1425-1477$ \\
\hline $5-1630.15$ & 85 & $\begin{array}{l}\text { Carbohydrate (c-o) of } \\
\text { polysaccharides, } \\
\text { Nucleic acid (other } \\
\text { phosphate containing } \\
\text { compound ) } \\
>\mathrm{p}=\mathrm{o} \text { stretching of } \\
\text { phosphodiester }\end{array}$ & $1072-1356$ \\
\hline $6-1429.4$ & 90.90 & $\begin{array}{c}\text { Carbohydrate (c-o) of } \\
\text { polysaccharides, } \\
\text { Nucleic acid (other } \\
\text { phosphate containing } \\
\text { compound ) } \\
\text { >p=o stretching of } \\
\text { phosphodiester }\end{array}$ & $1072-1356$ \\
\hline 7-1382.7 & 80 & $\begin{array}{r}\text { acid chlorides } \\
\text { stretch }\end{array}$ & $730-550$ \\
\hline $8-1175.577$ & 100 & $\begin{array}{r}\text { acid chlorides } \\
\text { stretch }\end{array}$ & $730-550$ \\
\hline 9-1037.5.992 & 90 & $\begin{array}{r}\text { acid chlorides } \\
\text { stretch }\end{array}$ & $730-550$ \\
\hline $10-936.27$ & 103 & $\begin{array}{r}\begin{array}{r}\text { acid chlorides } \\
\text { stretch }\end{array} \\
\end{array}$ & $730-550$ \\
\hline $11-880.34$ & 104.166 & $\begin{array}{r}\begin{array}{r}\text { acid chlorides } \\
\text { stretch }\end{array} \\
\mathrm{C}-\mathrm{Cl} \\
\end{array}$ & $730-550$ \\
\hline $12-818.634$ & 101 & $\begin{array}{r}\begin{array}{r}\text { acid chlorides } \\
\text { stretch }\end{array} \\
\end{array}$ & $730-550$ \\
\hline $13-664.357$ & 95 & $\begin{array}{r}\text { acid chlorides } \\
\text { stretch }\end{array}$ & $730-550$ \\
\hline $14-562.148$ & 92 & $\begin{array}{r}\begin{array}{r}\text { acid chlorides } \\
\text { stretch }\end{array} \\
\text { C-Cl }\end{array}$ & $730-550$ \\
\hline
\end{tabular}




\subsection{Energy dispersive X-ray (EDX):}

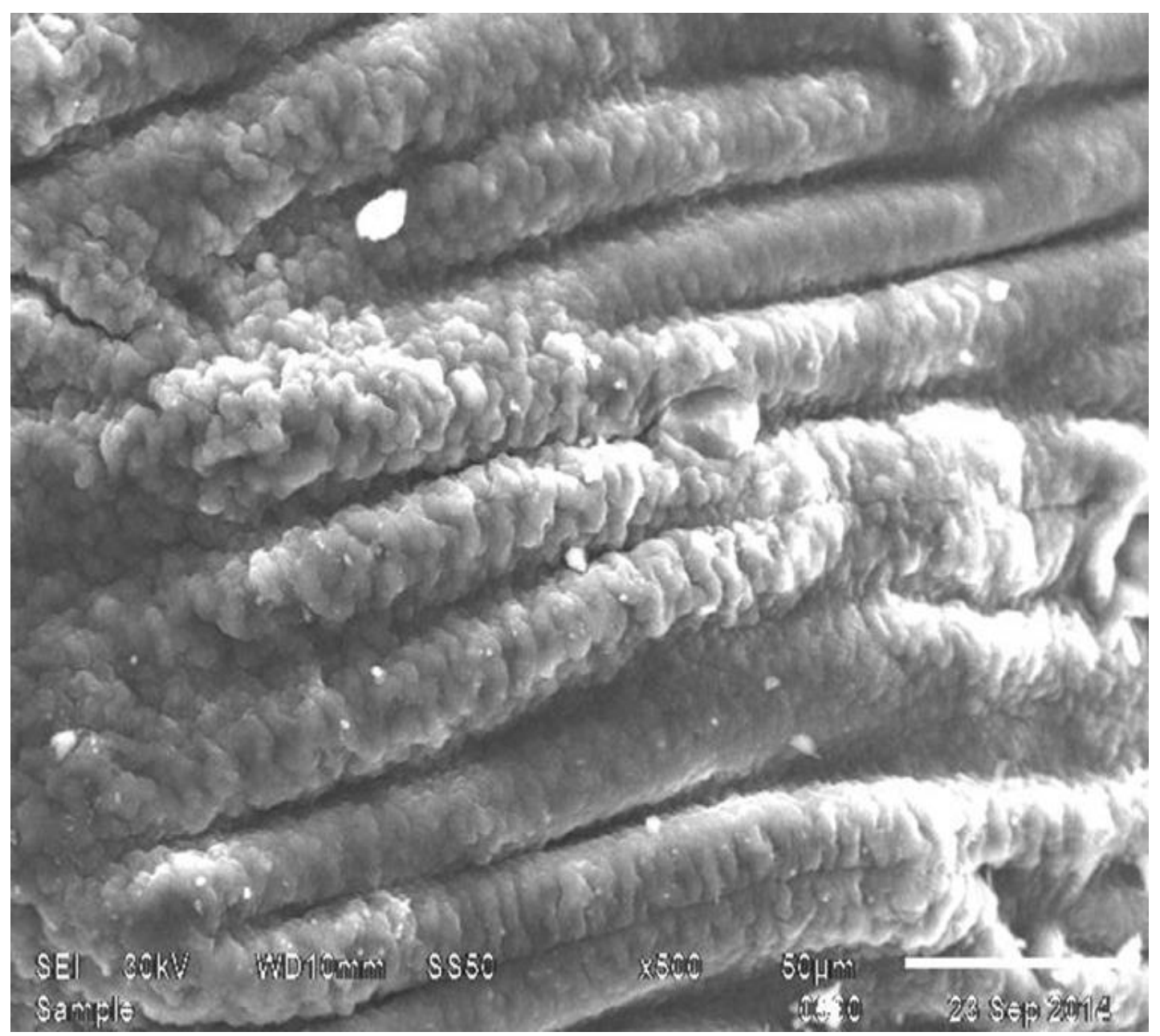

Figure 1- (EDX) to confirm Bio-sorption of U by Capsulated CellFree Extract Loaded Ca-Alginate Beads.

The alginate beads (Fig. 1), predominantly ellipsoidal spheres, with average diameter of 3-5 mm were used in the packed bed to remediate 10-1000 ppm U (VI) in a synthetic Uranium solution. The effectiveness of different dosages of beads was considered and the optimized ratio of 1:5 (v/v) of beads to water was used in all batch 
studies of isotherm kinetics. Scanning electron microscopic of these beads, Synthetic Solution (Fig.1), Control(Fig.2), showed that these were hollow from inside (having smooth inner wall In SEM/EDS analysis of the Ca-alginate beads after the experiment, void spaces of the beads were found to be filled with precipitates of heavy metals, showing that Ca-alginate beads can be successfully used as a biosorbent for the removal of Uranium and which agreed with (Sumin Park and Minhee Lee 2017) in in Substantial metal evacuation like $\mathrm{Cu}$,Cd. The picture of the control demonstrates nonappearance of any metal besides to Uranium, which as of now not present. While in Fig.1,2, , 3,4, Indicated Uranium as Fig. 3,4. In the spot zone affirmed Uranium bio-sorption.

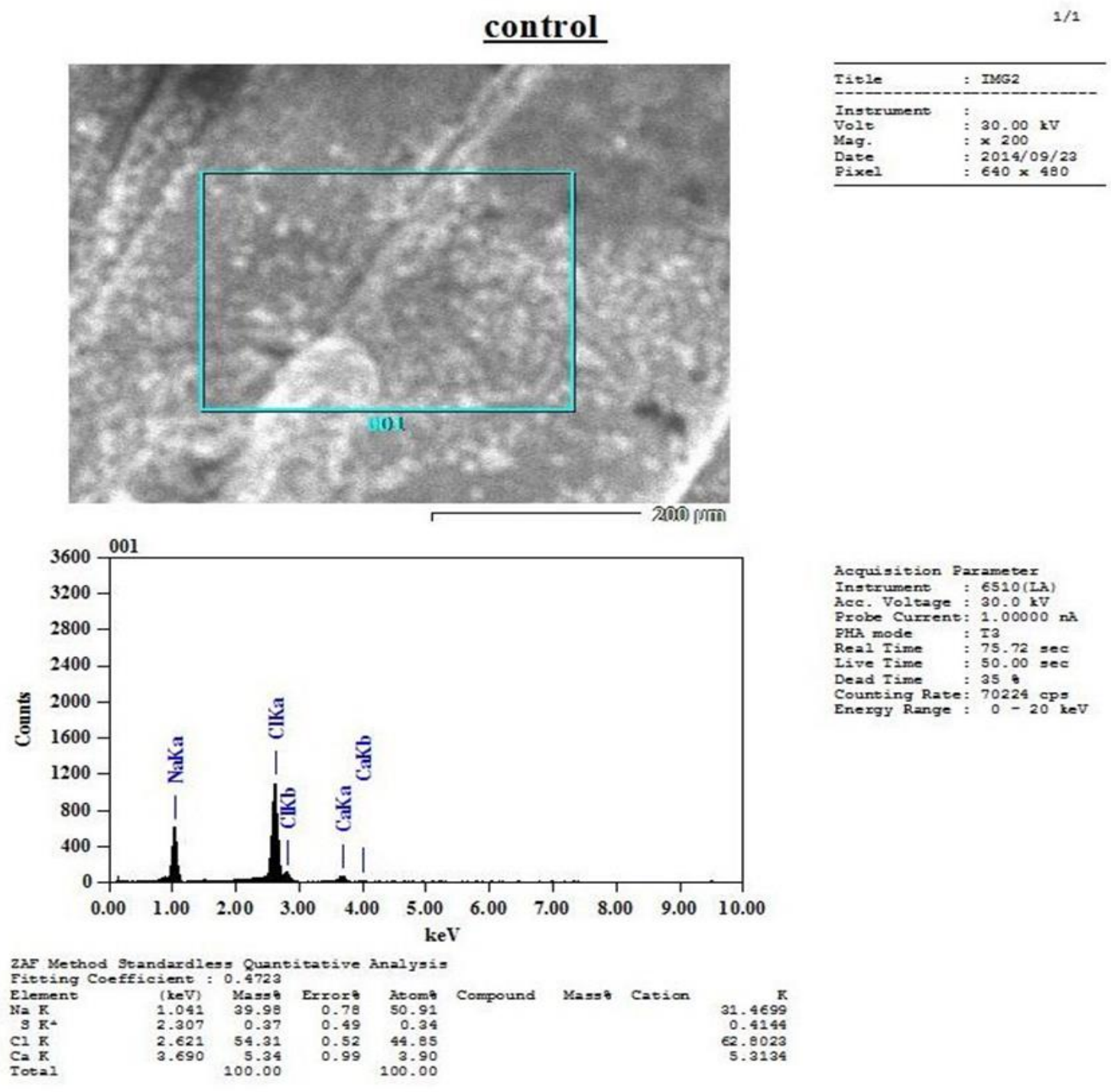


Figure 2- (EDX) to confirm Bio-sorption of $U$ by capsulated Cell-Free Extract Loaded Ca-Alginate Beads

(Fig. 3). This established the fact that E. coli interacted with the metal present in the medium.

Fig. 3 Bioremediation of $600 \mathrm{ppm}$ U (VI) from synthetic solution in bottle

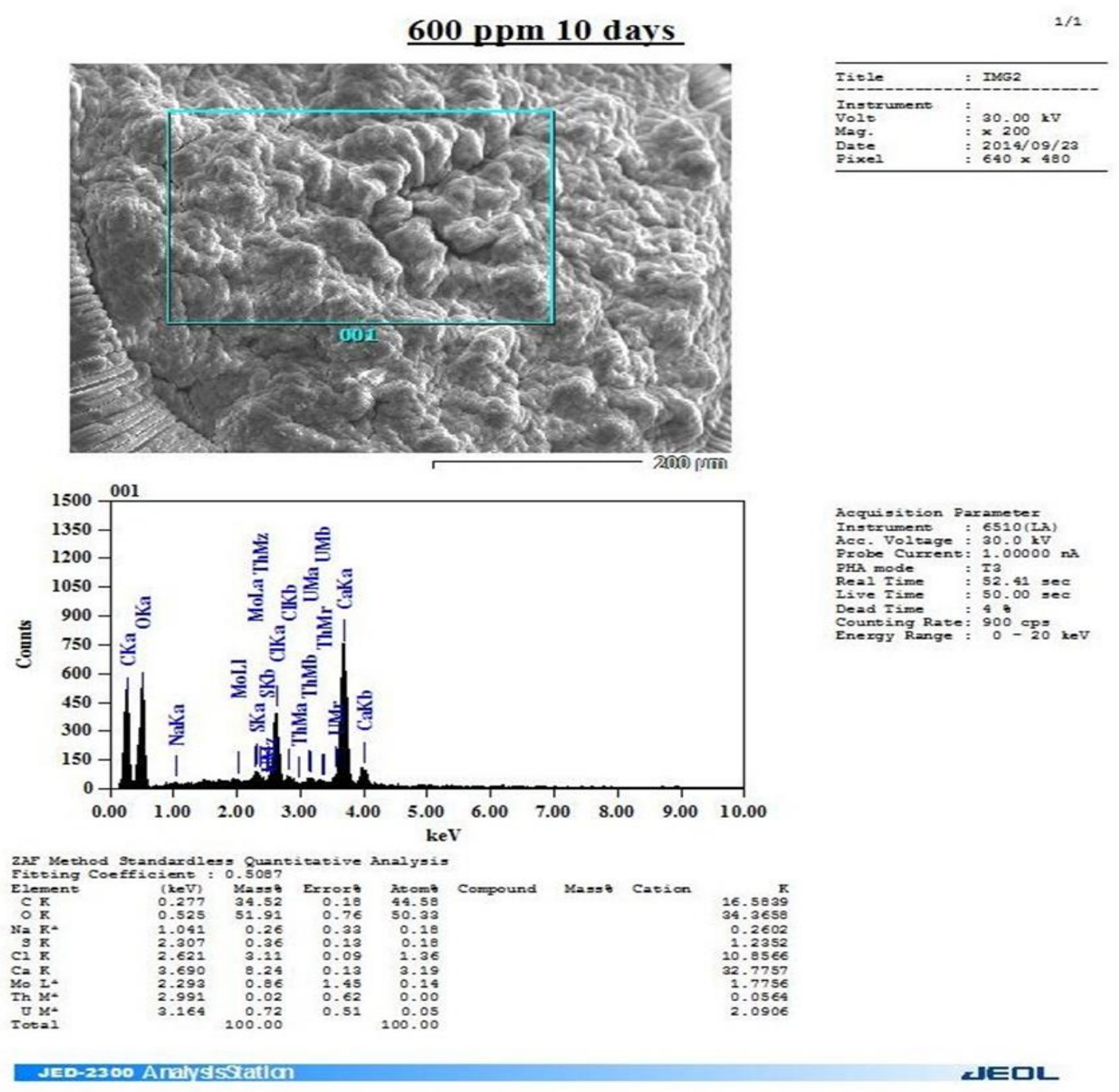


Peak Find - Memory-25

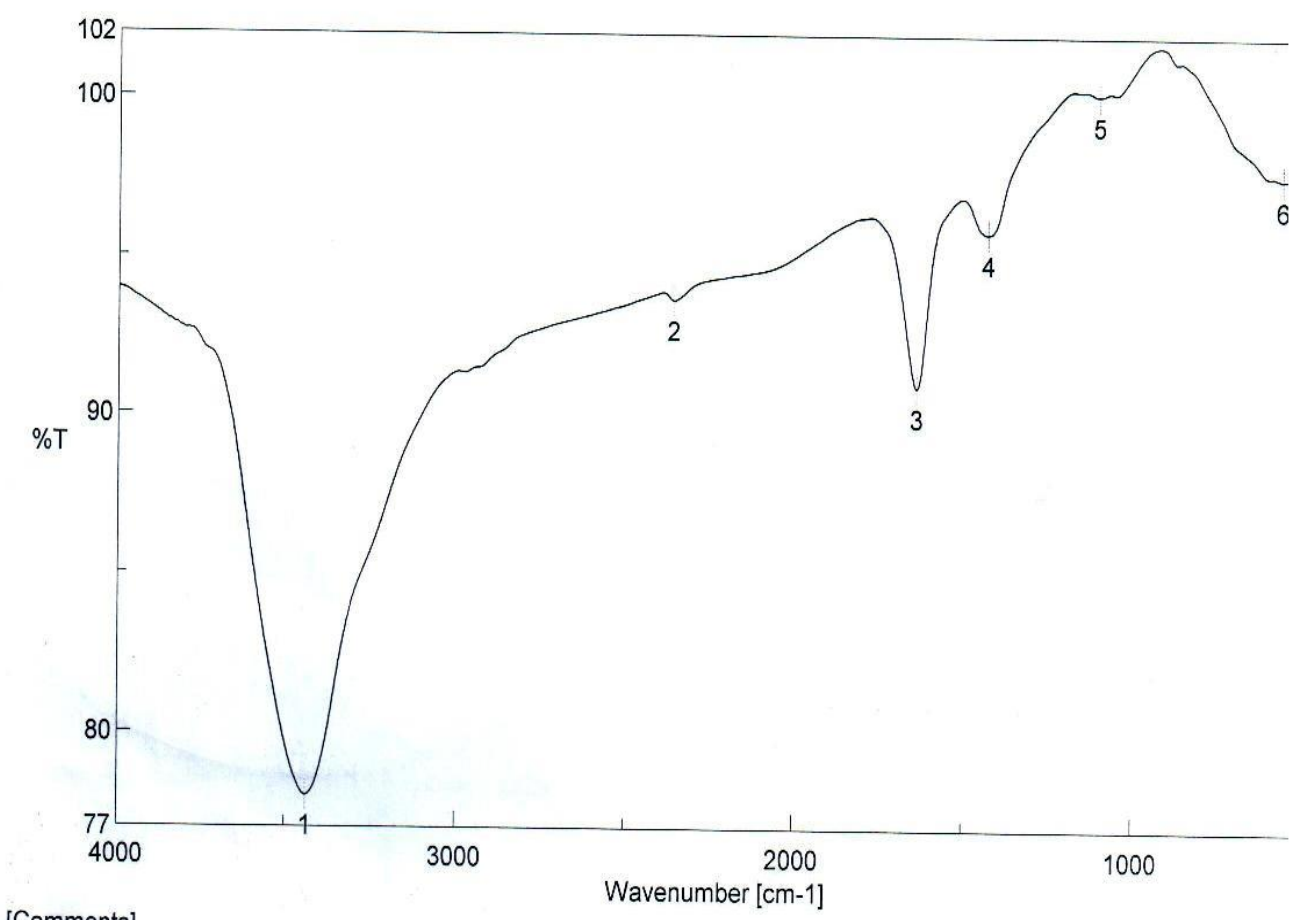

[Comments]

Sample name A

Comment 18/7/2017

User

IR

Division

IR

Company

MAC

[ Result of Peak Picking ]

$\begin{array}{lll}\text { No. } & \text { Position } & \text { Intensity } \\ 1 & 3439.42 & 77.9897\end{array}$

No. Position Intensity

$\begin{array}{lll}2 & 2355.62 & 93.6388\end{array}$

$\begin{array}{lll}\text { No. } & \text { Position } & \text { Intensity } \\ 3 & 1638.23 & 90.9209 \\ 6 & 556.363 & 97.5615\end{array}$

$\begin{array}{lll}4 & 1428.99 & 95.7948\end{array}$

$\begin{array}{lll}5 & 1101.15 & 100.155\end{array}$

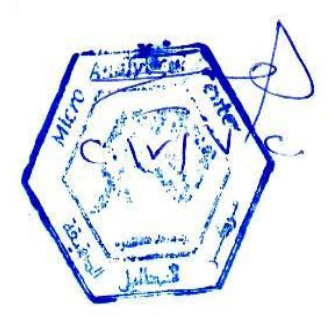

Fig.4 the IR Spectrum of Live E. coli before Bio-sorption Process. 
Kazy et al. (2006) utilized X-beam diffraction (XRD) examination and affirmed the inclusion of cell carboxyl and phosphate bunches in the authoritative of lanthanum by Pseudomonas biomass. SEM micrographs have supported analysts in dissecting cell surface morphology prior and then afterward bio-sorption. Tunali et al. (2006) envisioned the surface of metal-stacked Bacillus sp. while in our investigation we utilized SEM helped us in affirming U bio-sorption.

\section{IR Examination of Cell wall of $E$. coli:}

Cell wall of $E$. coli used in bio-sorption showing Function group in cell wall and comparing it with autoclaved forms exploring difference in intensity of function group of cell wall which involved in bio-sorption this difference in intensity Reflected in bio-sorption capacity as showed in figure $\mathbf{4}$ function group and its intensity in case of free cell.

\subsection{Comparative study showing different forms of Bacterial}

\section{Biomass.}

Table: 6. Treatment for different form of sample and applications.

\begin{tabular}{|c|c|c|c|}
\hline Bio-sorption\% & $\begin{array}{c}\text { Immobilized } \\
\text { Bacteria }\end{array}$ & $\begin{array}{c}\text { Autoclaved } \\
\text { bacteria }\end{array}$ & $\begin{array}{c}\text { Free } \\
\text { bacterial } \\
\text { cell }\end{array}$ \\
\hline Standard Uranium 100ppm & $100 \%$ & $80 \%$ & $65 \%$ \\
\hline Waste water (low conc.) & $100 \%$ & $100 \%$ & $70 \%$ \\
\hline Phosphoric acid(40PPM) & $90 \%$ & $50 \%$ & $60 \%$ \\
\hline
\end{tabular}

\subsection{Relation between Immobilization of Cells and efficiency of bio- sorption:}

Immobilized individual enzymes can be successfully used for single-step reactions. They are, however, not suitable for multi-enzyme reactions and for the reactions requiring cofactors. The whole cells or cellular organelles can be immobilized to serve as multi-enzyme systems. In addition, immobilized cells rather than enzymes 
are sometimes preferred even for single reactions, due to cost factor in isolating enzymes. For the enzymes, which depend on the special arrangement of the membrane, cell immobilization is preferred. Immobilized cells have been traditionally used for the treatment of sewage. The techniques employed for immobilization of cells are almost the same as that used for immobilization of enzymes with appropriate modifications. Entrapment and surface attachment techniques are commonly used. Gels, and to some extent membranes, are employed.

\section{Immobilized live Cells:}

The viability of the cells can be preserved by mild immobilization. Such immobilized cells are particularly useful for fermentations. Sometimes mammalian cell cultures are made to function as immobilized viable cells.

\section{Immobilized dead Cells:}

In many instances, immobilized non-viable cells are preferred over the enzymes or even the viable cells. This is mainly because of the costly isolation and purification processes. The best example is the immobilization of cells containing glucose isomerase for the industrial production of high fructose syrup.

Data showed in table 6 reveal that bacterial isolate can treat different forms of wastes and show that immobilized bacterial isolate gain high protection enable it to treat waste with high acidity like Phosphoric acid while free cell of the same bacterial isolate can not treat this type of waste so can't complete bio-sorption process with the same efficiency so we found that immobilized bacterial isolates with bio-sorption efficiency reach $100 \%$ and $90 \%$ respectively in case of standard Uranium, and Phosphoric acid, where immobilization Provide high number of active sites as mentioned above in table $5 \mathrm{c}, 5 \mathrm{~d}$ entrapment imparts mechanical strength and resistance to chemical and microbial degradation upon the bio-sorbent, the costs of immobilizing agent cannot be ignored. Free cells are not suitable for use in a column; due to their low density and size they tend to plug the bed, resulting in marked declines in pressure. For industrial applications, as in our study we made alginate beads like (capsule) of bio-sorption, it is important to utilize an appropriate immobilization technique to prepare commercial bio-sorbents, which retain the ability of microbial biomass to adsorb metal(s) during the continuous treatment process. The 
immobilization of biomass in solid structures would create a bio-sorbent material with the right size, mechanical strength, rigidity, and porosity necessary for use in practical processes. The immobilized materials can be used in a manner similar to ionexchange resins and activated carbon such as adsorption-desorption cycles

\subsection{Effect of desorption study}

Table: 7. Desorption ratio of uranium ions adsorbed by Coli. /alginate

\begin{tabular}{|c|c|c|c|c|c|}
\hline No of cycle & $\mathbf{1}^{\text {st }}$ & $\mathbf{2}^{\text {nd }}$ & 3rd & 4th & 5th \\
\hline $100 \mathrm{ppm}$ & $100 \%$ & $100 \%$ & $100 \%$ & $100 \%$ & $100 \%$ \\
\hline $250 \mathrm{ppm}$ waste & $100 \%$ & $100 \%$ & $100 \%$ & $100 \%$ & $100 \%$ \\
\hline ppm500 & $100 \%$ & $100 \%$ & $100 \%$ & $100 \%$ & $100 \%$ \\
\hline $1000 \mathrm{ppm}$ & $\% 100$ & $100 \%$ & $100 \%$ & $100 \%$ & $95 \%$ \\
\hline
\end{tabular}

The proposed procedure could be practical in performing remediation on location particularly for the emanating of enterprises. The real preferred standpoint of operation could be typical natural conditions under which the dots work productively. Subsequently, the curiosity of this proposed Work was because of the work of strain E. coli $\mathrm{sp}$. whose healing limit in all structures (whole cell, crude Eluents \% recovery Time taken (hr.) Desorption ratio Beads' condition (post-desorption)

\begin{tabular}{|c|c|c|c|c|}
\hline $\begin{array}{c}\text { Elluents } \\
\mathbf{1 M ~ H N 0}_{3}, \mathbf{C a c l}_{\mathbf{2}}\end{array}$ & \% Recovery & Time(hr.) & $\begin{array}{c}\text { Desorption } \\
\text { Ratio }\end{array}$ & Beads(post Desorption) \\
\hline 10 & $100 \%$ & 24 & $100 \%$ & Intact Bead \\
\hline 50 & $100 \%$ & 24 & $100 \%$ & Intact Bead \\
\hline 100 & $100 \%$ & 24 & $100 \%$ & Intact Bead \\
\hline 250 & $100 \%$ & 24 & $100 \%$ & Intact Bead \\
\hline 500 & $100 \%$ & 24 & $100 \%$ & Intact Bead \\
\hline 1000 & $98 \%$ & 24 & 98 & \\
\hline
\end{tabular}

Table 8 Desorption study of used CFE-loaded Ca-alginate beads

Along these lines, it is important to assess the appropriate elutant volume, which can be performed utilizing explores different avenues regarding distinctive strong to 
liquid proportions. The strong to-fluid proportion is characterized as the mass of solute-loaded bio-sorbent to the volume of elutant. Davis et al. (2000) watched that strong to-fluid proportion influenced copper elution effectiveness of $\mathrm{Cacl}_{2}$ arrangements, while it was about free on account of $0.1 \mathrm{M} \mathrm{HCl}$. The reason for desorption is to unbind a contaminant from a bio-sorbent, so both the recouped solute and bio-sorbent can be reused. After desorption, the bio-sorbent ought to be near its unique shape, both morphologically and practically. Additionally, amid the desorption procedure; expulsion of all bound sorbate from bio-sorbent ought to be guaranteed. On the off chance that this does not happen, a decreased take-up ought not out of the ordinary in the following cycle. Puranik and Paknikar (1999) recovered and reused a polysulfone-immobilized Citrobacter strain more than three cycles for the biosorption of lead, cadmium, and Zinc, utilizing $0.1 \mathrm{M} \mathrm{HCl}$ and $0.1 \mathrm{M}$ EDTA as elutants, yet just with constrained achievement, and accentuated the requirement for additionally screening work. Beolchini et al. (2003) immobilized Sphaerotilus natans into a polysulfone framework for the bio-sorption of copper, and with the guide of $0.05 \mathrm{M} \mathrm{Cacl} 2$ recovered and reused the dabs more than ten cycles with tasteful outcomes.

Table: 9. Decrease in \% bioremediation due to desorption from beads after each sorption cycle

\begin{tabular}{|c|c|c|c|c|c|}
\hline No of cycle & $\mathbf{1}^{\text {st }}$ & 2nd & 3rd & 4th & 5th \\
\hline $100 \mathrm{ppm}$ & $100 \%$ & $100 \%$ & $100 \%$ & $100 \%$ & $100 \%$ \\
\hline $250 \mathrm{ppm}$ waste & $100 \%$ & $100 \%$ & $100 \%$ & & \\
\hline ppm500 & $100 \%$ & $100 \%$ & $100 \%$ & $100 \%$ & $100 \%$ \\
\hline $1000 \mathrm{ppm}$ & $97 \%$ & $95 \%$ & $95 \%$ & $95 \%$ & $95 \%$ \\
\hline
\end{tabular}

Desorption think about: Out of the different eluents utilized, $0.5 \mathrm{M} \mathrm{HNO}_{3}$ ended up being the most productive. The desorption apportion is given by: Desorption ratio $=$ [Amount of $\mathrm{U}(\mathrm{VI})$ particles in desorption medium/Same adsorbed in beads] $\times 100$ (Table 9). It was discovered that a cluster of dabs dose could perform bioremediation up to 5 cycles all together (15 days). What's more, ready to finish 
more than additional 5 cycle Past 5 cycles, the dots not swelled up and not contorted. This may be because of the corrosive increment it's strength and unbending nature denaturation of alginate-protein connection by desorption treatment and the came about medicinal rate likewise diminished sans cell separate and epitomized in bioploymeric hydrogel dabs) has been high (93-99.7 \%) and utilization of an extraordinary reused connect stream model to semi-cluster method of adsorption. Kuyucak and Volesky (1989) analyzed a few synthetic operators to desorb $\mathrm{Co}^{2+}$ from cobalt-loaded Ascophyllum nodosum, and distinguished $\mathrm{CaCl}_{2}$ within the sight of $\mathrm{HCl}$ as a reasonable elutant. The execution of an elutant additionally unequivocally relies upon the sort of system in charge of bio-sorption. For example, electrostatic fascination was observed to be the essential system in charge of bio-sorption of contrarily charged color anions to a decidedly charged cell surface (O'Mahony et al. 2002). In this way, it is coherent to influence the cell to surface negative utilizing antacid answers for repulse the adversely charged responsive colors (Won and Yun 2008). Elution is likewise affected by the volume of elutant, which ought to be as low as for all intents and purposes conceivable to acquire the most extreme solute focus in the littlest conceivable volume (Volesky 2001). In the meantime, the volume of the arrangement ought to be adequate to give most extreme solvency to the desorbed solute. Likewise, one needs to understand that the desorbed sorbate remains in arrangement, another harmony is set up amongst that, and the one (staying) still settled on the biosorbent. This prompts the idea of a "desorption isotherm" where the harmony is firmly moved toward the sorbate disintegrated in the arrangement (Yang and Volesky 1996).

\section{Conclusion:}

We endeavored to expel U from U wastewater tested at Nuclear Materials Authority utilizing microscopic organisms showing a noteworthy capacity to amass U. Suitable cells of $E$. coli were suspended in $100 \mathrm{~mL}$ of answer-immobilized microbes (pH 6.0) of wastewater containing $\mathrm{U}$ for $1 \mathrm{~h}$ at $25^{\circ} \mathrm{C}$. E. coli confined from Egypt U Metal expelled $90 \%$ and $78 \% \mathrm{U}$, separately (Table 15, 16), when arrangement $\mathrm{pH}$ was balanced at first to 6.0. Arrangement $\mathrm{pH}$ step by step diminished, with E. coli cells being all the more unfavorably influenced by $\mathrm{pH}$. Be that as it may, strains quantitatively expelled $\mathrm{U}$ when the $\mathrm{pH}$ was kept up at 6.0. These species would thus be able to expel $U$ from $U$ refining wastewater with a high productivity. Endeavors 
were likewise made to expel $U$ from $U$ refining wastewater utilizing immobilized microorganisms having a high capacity to adsorb U. Uranium refining wastewater (100 mL, pH 6.0) supplemented with $2.1 \mathrm{mM}$ of $\mathrm{U}$ were adsorbed on a segment (bed volume $2 \mathrm{~mL}$ ) of immobilized bacterial cells. Immobilized bacterial cells disconnected from $U$ mines in the Egypt can also remove $U$ from the $U$ refining wastewater with high efficiency U Sorption at Different condition incubation time $100 \mathrm{~min}$

\section{DECLARATIONS}

- ETHICAL APPROVAL AND CONSENT TO PARTICIPATE

Manuscripts Doesn't reporting studies involving human participants,

- CONSENT FOR PUBLICATION

Not Applicable

- AVAILABILITY OF DATA AND MATERIAL

"Please contact author for data requests."

- COMPETING INTERESTS

$\mathrm{t}$ "The authors declare that they have no competing interests."

- FUNDING

The authors have No Funds.

\section{References:}

1. Agarwal, G. S. Bhuptawat, H. K. and Chaudhari, S. 2006.

Biosorption of aqueous chromium(VI) by Tamarindus indica seeds.

Bioresour. Technol.

2. Abel, E., Ibrahim, N. and Huyop, F. (2012). Identification of Serratia marcescens SE1 and determination of its herbicide 2,2-dichloropropionate (2,2-DCP) degradation po tential. Malaysian Journal of Microbiology 8(4), 259-265.

3. Ahmad, M., F. Haydar, S. Bhatti, A. A. \& Bari, A. J. (2014). Application of artificial neural network for the prediction ofbiosorption capacity of 
immobilized Bacillus subtilis for the removal of cadmium ions from aqueous solution.Biochemical Engineering Journal, 84, 83-90.

4. An, B.R., Son, H.J. Chung, J.S. Choi, J.W. Lee, S.H. and Hong, S.W. 2013, Calcium and hydrogen effects during sorption of copper onto an alginate-based ion exchanger: Batch and fixed-bed column studies. Chemical Engineering Journal, 232, 51-58.

5. Andrade, S., Poblet, A. Scagliola, M. Vodopivez, C. Curtosi, A. Pucci, A. Marcovecchio, J. 2001. Distribution of heavy metals in surface sediments from an Antarctic marine ecosystem. Environ Monit Assess. 66:147-158.

6. Bauer, AW., Kirby, WMM. Sherris, JC. Turck, M. 1966. Antibiotic susceptibility testing by a standardized single disc method. Am J Clin Pathol. 45:493-496.

7. Chen, B.-Y., Chen, C.-Y. Guo, W.-Q. Chang, H.-W. Chen, W.- M. Lee, D.-J. Huang, C.-C. Ren, N.-Q. \& Chang, J.-S. (2014). Fixed-bed biosorption of cadmium using immobilized Scenedesmus obliquus CNW-N cells on loofa (Luffa cylindrica) sponge. Bioresource Technology, 160, 175-181.

8. Davies, W., and Gray, W. A. (1964) : Rapid and specific titrimetric method for the precise determination of uranium using iron sulphate as reductant. Tolanta.11:1203-1211.

9. Davison, J., 1999. Genetic exchange between bacteria in the environment. Plasmid. 42:73-91. 
10. Gadd, GM., (1990) Heavy metal accumulation by bacteria and other microorganisms. Experientia 46:834-839

11. Goldstein, FW. 2007. Combating resistance in a challenging, changing environment. Clin Microbiol Infect. 13:2-6.

12. Gourdon, R., Bhende, S. Rus, E. Sofer, SS. (1990) Comparison of cadmium biosorption by Gram-positive and Gram-negative bacteria from activated sludge. Biotechnol Lett 12:839-842

13. Hassen, A., Saidi, N. Cherif, M. Boudabous, A. 1998. Resistance of environmental bacteria to heavy metal. Bioresour Technol. 64:7-15.

14. Herreros, MA. Sandoval, H. González, L. Castro, JM. Fresno, JM. Tornadijo, ME. 2005. Antimicrobial activity and antibiotic resistance of lactic acid bacteria isolated from Armada cheese (a Spanish goats' milk cheese). Food Microbiol. 22:455-459.

15. Jackson, VA., Paulse, AN. Odendaal, JP.Khan, S. Khan, W. (2012) Identification of metal-tolerant organisms isolated from the Plankenburg river, western Cape, South Africa. Water SA 38: 29-38.

16. Kazy, S., K.Das, S. K. and Sar, P. 2006. Lanthanum biosorption by a Pseudomonas sp.: equilibrium studies and chemical characterization. J. Ind. Microbiol. Biotech. 33:773-83.

17. Kümmerer, K., 2009. Antibiotics in the aquatic environment - a review. Part II. Chemosphere. 75:435-441.

18. Lo, G. A., Casella, P. Bruni, V. Michaud, L. 2013. Response of bacterial isolates from Antarctic shallow sediments towards heavy 
metals, antibiotics and polychlorinated biphenyls. Ecotoxicology. 22:240-250

19. Lee, M., Huang, D.-J. Ren, C.-C. Chang, J.-S. \& N.-Q., (2014). Fixed-bed biosorption of cadmium using immobilized Scenedesmus obliquus CNW-N cells on loofa (Luffa cylindrica) sponge. Bioresource Technology, 160, 175-181.

20. Malik, A. Jaiswal, R. 2000. Metal resistance in Pseudomonas strains isolated from soil treated with industrial wastewater. World J Microbiol Biotechnol. 16:177-182.

21. Malik, P, Terry, TD. Bellintani , F. Perham, RN, (1998) Factors limiting display of foreign peptides on the major coat protein of filamentous bacteriophage capsids and a potential role for leader peptidase. FEBS Lett 436:263-266

22. Miller, RV., Gammon, K. Day, MJ. 2009. Antibiotic resistance among bacteria isolated from seawater and penguin fecal samples collected near Palmer Station, Antarctica this article is one of a selection of papers in the Special Issue on Polar and Alpine Microbiology. Can J Microbiol. 55: 37-45.

23. Mishra, V., Tadepalli, S. (2014) Biosorption of toxic heavy metals on sawdust. CLEAN Soil Air Water (Online). doi:10.1002/clen. 20130093

\section{Moskot, M., Kotlarska, E. Jakóbkiewicz-Banecka, J.}

GabigCiminska, M. Fari, K. Grzegorz, W. ' egrzyn, G. Wróbel, B.

2012. Metal and antibiotic resistance of bacteria isolated from the Baltic Sea. Int Microbiol. 15:131-139. 
25. Panda, J., \& Sarkar, P. (2012b). Isolation, identification, characterization and field application of $\mathrm{Cr}(\mathrm{VI})$ resistant bacteria. Journal of Environmental Science and Health, Part A, 47,237-244.

26. Panda, J., \& Sarkar, P. (2014). Biosensing and bioremediation of Cr(VI) by cell free extract of Enterobacter aerogenes T2. Journal of Environmental Science and Health, Part A, 49, 600-608.

27. Rani, MJ., Hemambika, B. Hemapriya, J. Kannan, VR. 2010. Comparative assessment of heavy metal removal by immobilized and dead bacterial cells: A biosorption approach. Afr J Environ Sci Technol. 4:077-083.

28. Ranquet, C., Ollagnier-de-Choudens, S. Loiseau, L. Barras, F. Fontecave, M. (2007) Cobalt Stress in Escherichia coli. The effect on the iron-sulfur proteins. J Biol Chem 282(42):30442-30451

29. Regine, HS., Vieira, F. Volesky, B. (2000) Biosorption: a solution to pollution. Int J Microbiol 3:17-24

30. Sabdono, A., Radjasa, OK. Utomo, HS. 2012. Screening of multimetal resistances in a bacterial population isolated fromcoral tissues of Central Java coastal waters, Indonesia. Int J Ocean Marine Ecol Syst. 1:11-23.

31. Séveno, NA., Kallifidas, D. Smalla, K. van Elsas, JD. Collard, JM. Karagouni, AD. Wellington, EMH. 2002. Occurrence and reservoirs of antibiotic resistance genes in the environment. Rev Med Microbiol. $13: 15-27$. 
32. Sharma, P., Kumari, P. Srivastava, M. M. and Srivastava, S. 2006. Romoval of cadmium from aqueous system by shelled Moringa oleifera Lam. Seed powder. Bioresour. Technol. 97:299-305.

33. Shevchuk, I. A., and Klimenko, N. I. 2009. Biological features of sorption of U (VII) and strontium ions by Bacillus polymyxa IMV 8910 cells. J. Water Chem. Technol. 31:324-328.

34. Sinha, A., Pant, K. K. \& Khare, S. K. (2012). Studies on mercury bioremediation by alginate immobilized mercury tolerant Bacillus cereus cells. International Biodeterioration \& Biodegradation, 71, 1-8.

35. Sumin, P., and Minhee, L. 2017 Removal of copper and cadmium in acid mine drainage using Ca-alginate beads as biosorbent Vol. 21, No. 3, p. 373-383, June 2017 pISSN 1226-4806 eISSN 1598-7477 .

36. Tomova, I., Gladka, G. Tashyrev, O. Vasileva-Tonkova, E. 2014. Isolation, identification and hydrolytic enzymes production of aerobic heterotrophic bacteria from two Antarctic islands.

Int J Environ Sci. 4:614-625.

37. Tunali, S., Çabuk, A. and Akar, T. 2006. Removal of lead and copper ions from aqueous solutions by bacterial strain isolated from soil. Chem. Eng. J. 115:203-211.

38. Veglio, F., Beolchini, F. (1997) Removal of metals by biosorption: a review. Hydrometallurgy 44:301-316

39. Zhang, XX., Zhang, T. Fang, HHP. 2009. Antibiotic resistance genes in water environment. Appl Microbiol Biotechnol. 82:397-414. 
40. Ziagova, M., Koukkou, A. I. \& Liakopoulou-Kyriakides, M. (2014).

Optimization of cultural conditions of Arthrobacter sp. Sphe3 for growthassociated chromate (VI) reduction in free and immobilized cell systems. Chemosphere, 95, 535-540. 